\title{
The relationship between Yoga exercises and social physical anxiety in athletic girls
}

\author{
Solmaz Babaei Bonab ${ }^{1}$, Morteza Fattah Pour Marandi ${ }^{2}$ \\ 1-Assistant professor, Sports Sciences, Department of Sports Sciences, University of Maragheh, Maragheh, Iran \\ (Corresponding Author). $\quad$ E-mail: s.babaei@maragheh.ac.ir \\ 2- Assistant professor, Sports Sciences, Department of Sports Sciences, University of Maragheh, Maragheh, Iran.
}

Received: 29/10/2019

Accepted: 23/12/2019

\begin{abstract}
Introduction: Social anxiety is one of the most common diseases of the modern age that has caused many disturbances in different areas of young girls lives and reduced their self-esteem.

Aim: The purpose of this study was The Relationship between Yoga Exercises and Social Physical Anxiety in Athletic Girls.

Method: This is a correlation-comparative study. The study population consisted of girls attending yoga classes. Of these, 201 were selected based on the Morgan table And the scale of physical activity and social anxiety was provided by Hart (1998). Pearson correlation test and regression analysis were used for data analysis.

Results: The results showed that there is a significant relationship between social anxiety and physical activity indices in the whole sample which is negatively correlated $(p<0.05)$. Thus, with the increase in each of the physical activity indices, the level of social anxiety decreased.

Conclusion: As a result, it can be said that exercise has additional benefits because it helps people feel better about themselves. Accordingly, maintaining a regular physical activity gradually reduces the motivational role of social anxiety and athletes achieve their goals in fitness.
\end{abstract}

Keywords: Athlete girls, Fitness, Physical activity, Physical social anxiety

How to cite this article : Babaei Bonab S, Fattah Pour Marandi M. The relationship between Yoga exercises and social physical anxiety in athletic girls. Shenakht Journal of Psychology and Psychiatry. 2020; 6 (6): 30-39 .URL: http://shenakht.muk.ac.ir/article-1-450-fa.pdf

Copyright $(\odot 2018$ the Author (s). Published by Kurdistan University of Medical Sciences. This is an open access article distributed under the terms of the Creative Commons Attribution-Non Commercial License 4.0 (CCBY-NC), where it is permissible to download, share, remix, transform, and buildup the work provided it is properly cited. The work cannot be used commercially without permission from the journal. 


\section{بررسى ارتباط بين تمرينات يوكا و اضطراب بدنى اجتماعى در دختران ورزشكار}

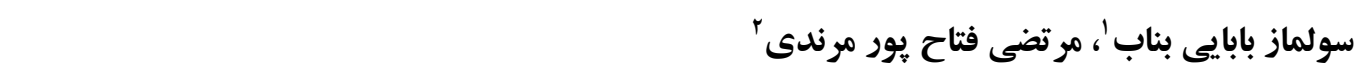

ا.استاديار، علوم ورزشى، گروه علوم ورزشى، دانشگاه مراغه، مراغه، ايران (مولف مسئول). ايميل: s.babaei@maragheh.ac.ir

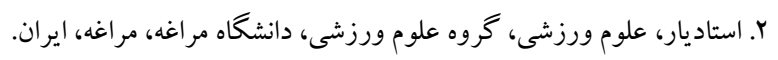

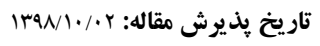

تاريخ دريافت مقاله: •

جكکبه

مقدمه: اضطراب بدنى اجتماعى بهعنوان يكى از بيمارىهاى شايع عصر حاضر كه عامل بسيارى از آشفتخى ها در زمينه هاى گوناكون

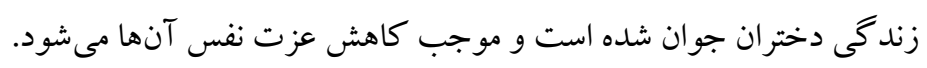

هدف: هدف از يزوهش حاضر بررسى ارتباط بين r ا هفته تمرين يو كا و اضطراب بدنى اجتماعى در دختران ورزشكار بود.

روش: مطالعه حاضر از نوع همبستكى - مقايسهاى است. جامعهى آمارى مطالعه، دختران شر كت كننده در كلاسهاى يو كا بودند كه از

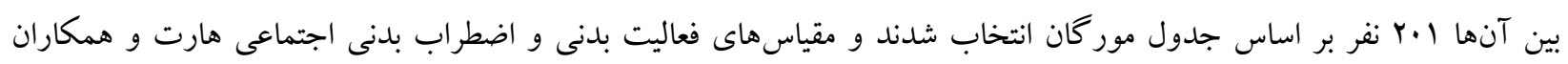

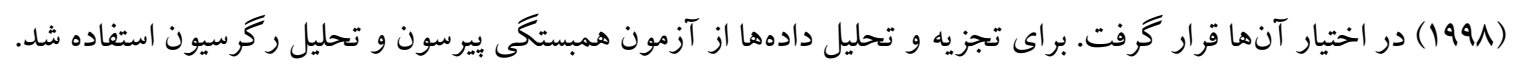
يافته ها: نتايج نشان داد كه بين اضطر اب بدنى اجتماعى و شاخصهاى فعاليت بدنى در كل نمونه آمارى ارتباط معنادارى وجود دارد

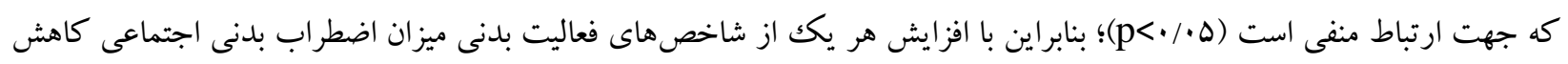
يافته است.

نتيجه كيرى: در نتيجه مى توان كفت كه ورزش سودمندىهاى مضاعفى دارد به اين دليل كه به افراد كمكك مى كند، احساس بهترى

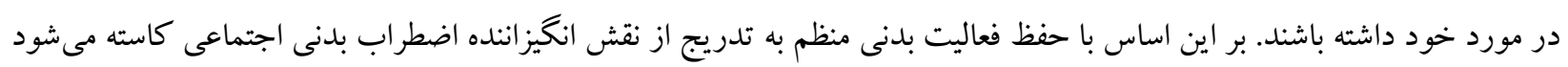
و ورزشكاران به اهداف خود در تناسب اندام مىرسند. كليد وازهها: زنان ورزشكار، تناسب اندام، فعاليتهاى بدنى، اضطراب بدنى اجتماعى 
كنند كه اين فرايند باعث به وجود آمدن اختلالات روانى

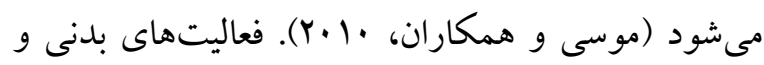
ورزش در شرايط كنونى در جوامع مختلف دنيا به صورت ضرورتى انكارنايذير يذيرفته شده است كه به شيوههاى مختلف انجام مىشود. از آن جمله تمرينهاى هوازى هميجون يو كا است كه به عنوان يكى از شيوههاى تمرينى براى كسب آمادكى جسمانى (هوازى) به كار مىرود. تمرينهاى يوكا وسيلهاى مناسب و ارزان قيمت برت در كاهش افسردگى خفيف تا متوسط است و از بروز آن

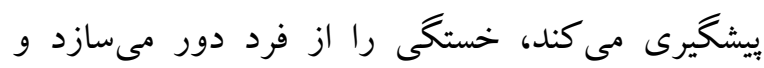

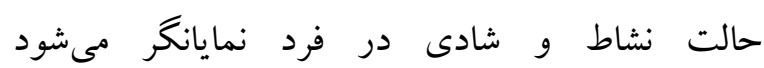

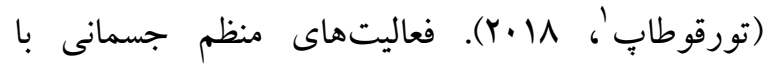
ييشخيرى از بسيارى از بيمارىها، باعث افزايش ميزان

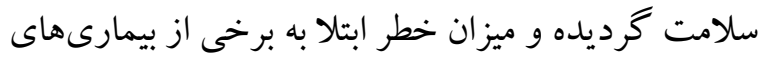
مزمن را كاهش مىدهد، كه به تبع آن موجب افزايش

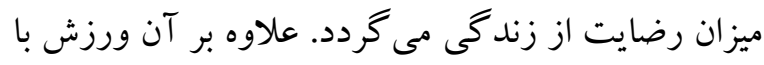
تأثيرى كه بر تناسب اندام و جاقى افراد دارد، مىتواند ميزان رضايت از زندگى افراد را افزايش دهد (باس و

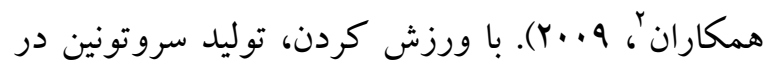
بلدن افزايش مىيابد كه باعث بالا بردن سطح هوشيارى و روحيه عمومى فرد شده، احساس انرزى و شادكامى بيشترى براى انجام كارهاى روزمره به شخص مى بخشد

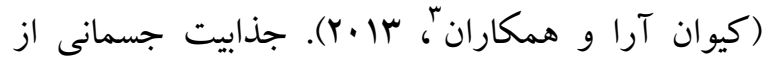
جمله موضوعاتى است كه در دوران مدرن استانداردهاى جديدى ييدا كرده و از عوامل شكل دهندهى روابط افراد محسوب مىشود، به طورى كه مديريت بدن امروزه اهميت بيشترى بيدا كرده است و رفتارهاى گُوناگون بهداشتى نظير بدنسازى، رزيمهاى غذايى، تجهيزات

1. Torgutalp

${ }^{2}$. Bosi et al

${ }^{3}$. Keyvanara et al مقلdمه در طول قرن بيستم انسان ازنظر شيوههاى زندگى، روابط اجتماعى و مسائل بهداشتى و يزشكى بيش از تمام تاريخ دستخوش دگر گونى شده است. تلاش شتابزده براى صنعتى شدن و گسترش سريع شهرنشينى و زندگى دالى ماشينى كه لازمه آن قبول شيوههاى نوين براى زندگى است، اثر معكوس بر سلامت انسان كذاشته و مسائل بهداشتى جديدى را به بار آورده است (نوروزيان و

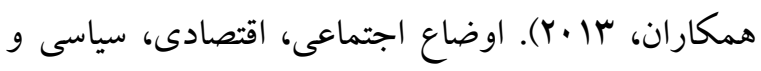
فرهنگى نابسامان جهان و بار مشكلات اجتماعى و

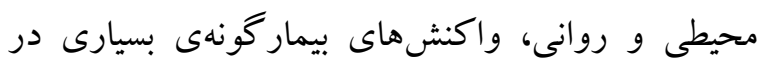
افراد و جوامع به وجود آورده است كه خود سبب وخيم شدن اوضاع و نامساعد شدن شرايط محيط زيست شده است و بدون شك در سلامت افراد جامعه اهميت به سزايى دارد (سيدنوزادى، سا.Y). دركشورهاى درحال توسعه شيوع جاقى به طور روزافزون در حال افزايش و سن جاقى كاهش يافته است، سازمان بهداشت جهانى تخمين زده است در دنيا بيش از يك بيليون بزرگكسال جاق و يا داراى اضافه وزن وجود دارد (يورشريفى و همكاران، F(Y. F). ايران نيز مانند ساير كشورها از اين معضل اجتماعى رنج مىبرد به طورى كه بررسىهاى ملى انجام شده در استانهاى مختلف كشور نشان داده است كه در F د درصد زنان، جاقى شكمى وجود دارد (رضايى و همكاران، · (Y). همراه با اين تغييرات داشتن تناسب اندام و وزن مناسب بين زنان اهميت زيادى بيدا كرده است. نمره بايين تناسب فيزيكى بدن مىتواند با افزايش

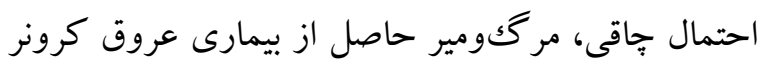
را بالا ببرد (عميدى و همكاران، ||(Y). زنانى كه وزن مناسبى ندارند معمولاً از فعاليت در جامعه خوددارى مى - 
به اضطرابى است كه فرد احساس مى كند شكل بدن او توسط ديخران ارزيابى مىشود (بيخدلى و همكاران؟،

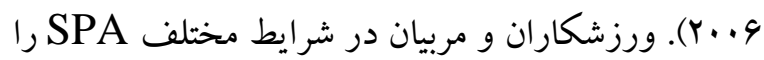

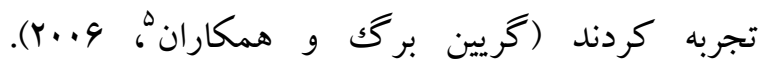
خوديذيرى فيزيكى به عنو ان يكك ويثز گیى اصلى ارائه شده

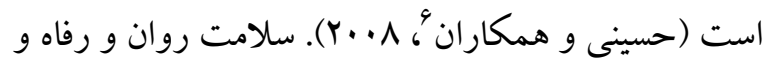
عدم وجود بيمارىها هم به عنوان واسطههاى ديخر

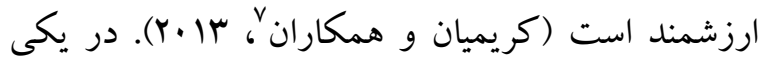
دو دهه اخير، در ايران داشتن اندام متناسب بسيار مورد توجه دختران و زنان بوده است. در هر جامعهاى يكك سرى الكوها در ارتباط با زيبايى اندام تعريف مىشود. از آنجا كه حساسيت زياد در بدن مىتواند مشكلات فراوانى همجِون كاهش اعتماد به نفس به وجود آورد لذا مىتوان برنامهاى مختلفى براى كاهش تأثيرات نامطلوب اين

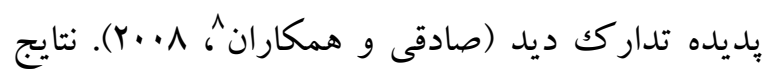
نشان مىدهد كه سه درصد از مردان و •V درصد از زنان خود را بزرگكتر و جاقتر از وضعيت ايده آل مىداند

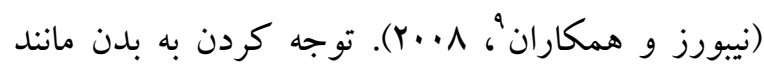

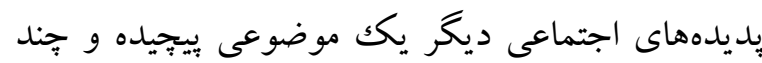

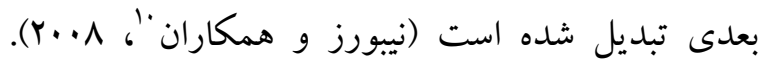
نتايج نشان دادند كه شركت در فعاليتهاى ورزشى ابزار مناسبى براى افزايش رفاه ذهنى، عواطف مثبت و رضايت بيشتر از زندگى و كاهش اضطراب است (ضيغمى و

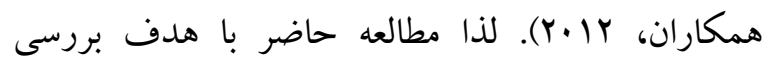
ارتباط بين تمرينات يو گا و اضطراب بدنى در زنان ورزشكار انجام شد.

${ }^{4}$. Bigdeli et al

5. Greenberg et al

${ }^{6}$. Hosseini et al

${ }^{7}$. Karimian et al

${ }^{8}$. Sadeghi et al

9 . Neighbors et al

${ }^{10}$. Neighbors et al
ورزشى و آرايشى مختلف در دوره جديد با تحولات جهانى شدن به مسئله بدن توجه بسيارى شده است كه عو املى از جمله بيشرفت براى مر اقبت از بدن بديدار شده

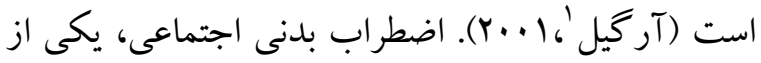
انواع اضطراب هاست كه به واسطه نقطه اثر تعاملى ميان بلدن و جامعه اهميت خاصى دارد با توجه به آنجه عنوان شد، به نظر مىرسد افراد برانخيخته مىشوند تا تصوير

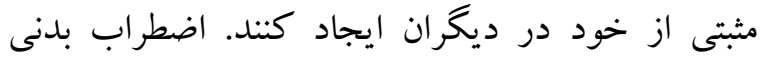
اجتماعى به تجربيات مردم اشاره مى كند زمانى كه آنها نغران ارزيابى بدنشان توسط ديخران هستند (غضنفرى و

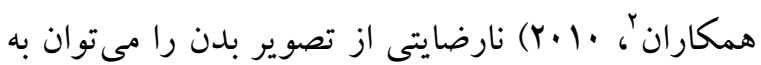
عنوان يكك انحراف درك،، رفتار يا شخصيت در ارتباط با وزن بدن تعريف كرد كه با عزت نفس يايين و و افسردگى مرتبط است. مدلهاى فرهنگى و اجتماعى نيز نشان دادهاند كه هنجارهاى فرهنگ برى براى لاغرى و زيبايى نقش بزرگى در اختلال تصوير ذهنى زنان ايجاد مى كند-

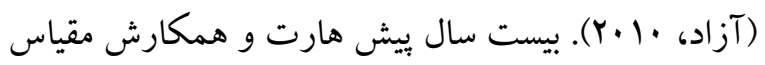
اضطراب فيزيكى اجتماعى را براى اندازه گيرى تمايلات

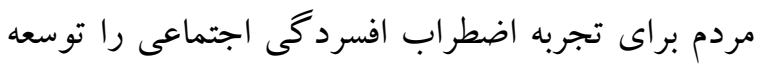

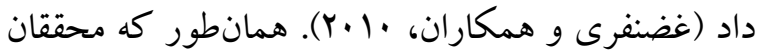
اشاره كردند، اضطراب اجتماعى در اصل به عنوان يكك

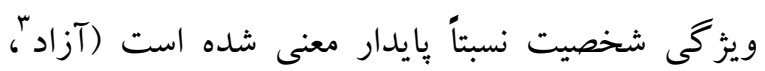
SPAS د. S.1. معمول به عنوان يكك بيش بينى كننده از ورزش و ساير رفتارهاى مرتبط با سلامتى و يا به عنوان يكك نتيجه از مداخلات براى بهبود تصوير بدن طراحى شده است، با بالب

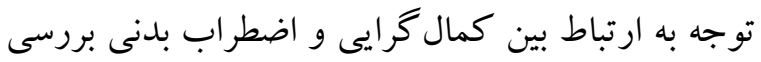

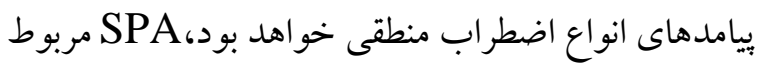

1. Argayl
2. Ghazanfari et al
3. Azad et al 
رضايت نامه كتبى از آنها براى حضور در بثزوهش گرفته

شد. نمونهاى انتخاب شده بين (بr-1) ساله و سالم بود. سيس برسشنامهها بعد از يكك هفته جمع آورى شد. از

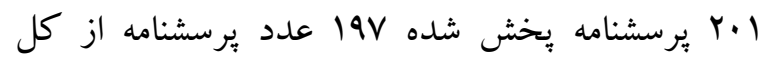

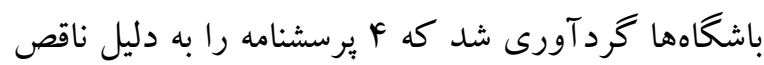
بودن اطلاعات حذف كرديم. معيار ورود به مطالعه عبارت بودند از: داشتن شرايط سنى \1 تا سץ سال، انجام فعاليتهاى يو كا به مدت بيش از r سال، داشتن شرايط جسمانى سالم، عدم مشكلات ارتويدى، عدم بيروى از رزيم غذايى خاص و عدم مصرف داروى خاص و معيار خروج از مطالعه عبارت بودند از: استفاده از رزيم غذايى و داروى خاص و عدم ير كردن صحيح برسشنامه ها. اطلاعات تكميلى در ارتباط با سن، سابقه و رشته در جدول شماره ا آورده شده است.
روش تحقيق حاضر همبستخى - مقايسهاى است. جامعه

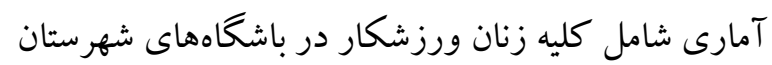
بناب است. نحوه انجام مطالعه بدين شرح بود كه ابتدا

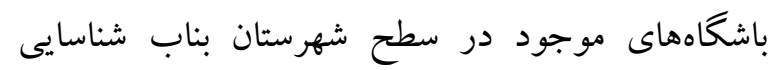
شدند. سيس با هماهنگى با مديريت باشكاهها و توضيح ضرورت تحقيق مقدمات يُزوهش فراهم شد. جامعه آمارى •Fr نقر از دختران ورزشكار در سطح باشگاهها

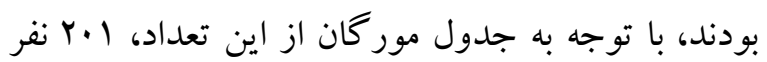
به عنوان نمونه به صورت تصادفى انتخاب شدند. يس از مراجعه به افراد و توضيح هدف مطالعه براى آنان و اخذ رضايت از آنان جهت شركت در مطالعه، برسشنامههاى فعاليت بدنى بكك و اضطراب بدنى بين آنها بخش شد. سبس در يكك جلسه توجيهى به افراد شركت كننده در يثزوهش هدف از مطالعه توضيح داده شد و همجنين

\begin{tabular}{|c|c|c|c|c|}
\hline \multicolumn{5}{|c|}{ جدول ا ويزگحىهاى جمعيت شناختى آزمودنىها } \\
\hline ميانغين سابقه (سال) & بيشينه سن & كمينه سن & ميانغين سنى (سال) & تعداد نمونه \\
\hline$r$ & $r$ & 11 & IN-rr & $r \cdot 1$ \\
\hline
\end{tabular}

فعاليت ورزشى و فعاليت بدنى مربوط به شغل تنظيم شده

و با توجه به بخشها و جوابهاى مربوطه، از امتياز ه-1

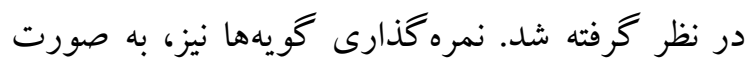
ليكرت با سه مؤلفه محل كار، فراغت و ورزش بود. براى تعيين بايايى درونى برسشنامه، از آزمون آلفاى كرونباخ استفاده گرديد ـ مقادير به دست آمده براى اين برسشنامه، V9 / V9 نمود.

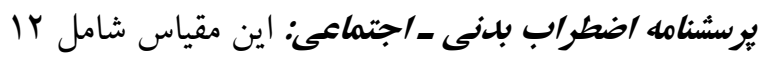
كويه است كه توسط هارت و همكاران (1919) براى در يزوهش حاضر براى جمع آورى اطلاعات از دو برسشنامه فعاليت بدنى بك و مقياس اضطراب بدنى برونى اجتماعى استفاده شده است كه هر يكك از اين ابزارها جداگانه معرفى مىشوند. برسشامه فعاليت بلنى بك: بررسى سطح فعاليت بلنى

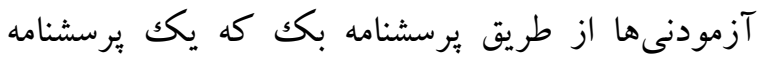
استاندارد بين المللى براى ارزيابى سطح فعاليت بدنى است و توسط مراكز علمى از جمله دانشكاه علوم يزشكى ايران و دانشگاه تهران ترجمه شده است، انجام كرفت. اين يرسشنامه شامل 19 كويه بود كه در سه بخش: كار، 


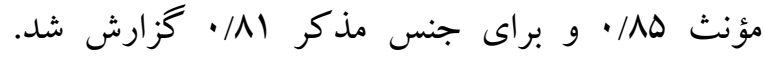
همجنين روايىسازه اين مقياس، توسط طباطبائيان و

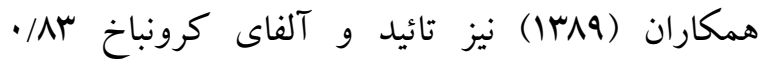
محاسبه شده است. در اين يزوهشها نيز ثبات درونى اين مقياس روى نمونه ·له نفره، هA/· ارزيابى شده است. به له منظور رعايت موازين اخلاق بزوهش، برسشنامه ها به صورت بى نام توزيع شد. به منظور تجزيه و تحليل داده ها از آزمونهاى شاييرو

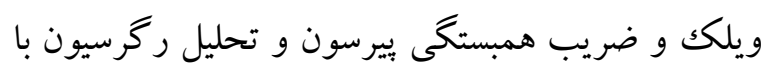
استفاده از نرم افزار SPSS نسخه إ استفاده گرديد.

\section{يافتهها} براى تحليل دادههاى حاصل، ابتدا بررسى طبيعى بودن توزيع دادهها مورد نياز است. براى بررسى طبيعى بودن

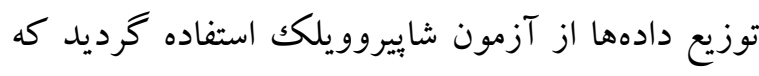
نتايج در جدول شماره Y گزارش شده است.
ارزيابى اضطراب اجتماعى اندام ساخته شد كه مقدار اضطراب فرد در مورد شكل اندام را در موقعيتهاى اجتماعى مىسنجد. اين ابزار بر اساس مقياس ه ارزشى

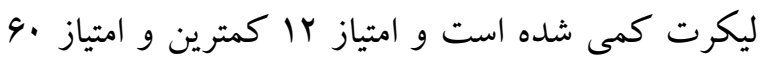
بيشترين اضطراب را نشان مىدهد. به هر گويه، نمرهاى

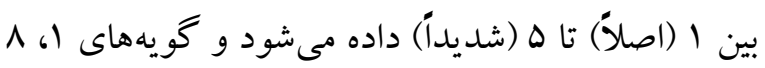
و البهصورت معكوس نمره گذارى مىشوند. به دست آوردن نمره بالا به معنى داشتن اضطراب بدنى اجتماعى لهوري بيشتر است. يس از تدوين يرسشنامه بهوسيله هارت و و بهر همكاران (1919) مطالعات زيادى درصدد رواسازى آن

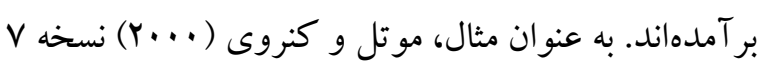
گُيهاى اين مقياس را رواسازى كردند و ويثز گهىهاى روانسنجى آن را تائيد كردند. نسخه فارسى اين ابزار بهوسيله يوسفى و همكاران (MNAN) در بين دانشجويان

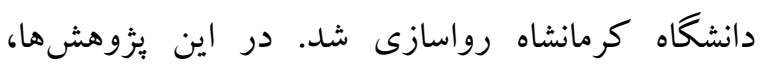
همسانى درونى يا محاسبه آلفاى كرونباخ، براى جنس دراه
مى گردد و مىتوان از آزمونهاى پِارامتريك استفاده نمود؛ بنابر اين براى بررسى ارتباط بين متغيرهاى تحقيق از آزمون ضريب همبستكى بيرسون استفاده شد (جدول س).
نتايج جدول شماره r نشان مىدهد كه سطح معنادارى به دست آمده از ه•/ • بالاتر است. از آنجا كه بالاتر بودن سطح معنادارى در اين آزمون نشاندهنده طبيعى بودن توزيع داده هاست، لذا فرض طبيعى بودن توزيع داده تائيد

جدول ل ضرايب همبستغى بين شاخص هاى فعاليت بدنى و اضطر اب بدنى اجتماعى

\begin{tabular}{|c|c|c|c|c|c|c|c|c|}
\hline$\Delta$ & $p$ & $r$ & $r$ & 1 & انحر اف معيار & ميانغين & متغير & \\
\hline & & & & 1 & .191 & $r / 90$ & شاخص كار & 1 \\
\hline
\end{tabular}




\begin{tabular}{|c|c|c|c|c|c|c|c|}
\hline & & 1 & $\cdot / \Delta \cdot 1$ 米米 & \multirow[t]{2}{*}{$\cdot / 09$} & \multirow[t]{2}{*}{$r / F \wedge$} & \multirow[t]{2}{*}{ شاخص ورزش } & \multirow[t]{2}{*}{$r$} \\
\hline & & - & $\cdot / \cdots 1$ & & & & \\
\hline & 1 & $\cdot / 4 \|$ 药* & • & \multirow[t]{2}{*}{$\cdot / 49$} & \multirow[t]{2}{*}{$r / T V$} & \multirow{2}{*}{ شاخص اوقات فراغت } & \multirow[t]{2}{*}{$r$} \\
\hline & - & $\cdot / \cdot \cdot 1$ &.$/ .4 q$ & & & & \\
\hline 1 & $-\cdot / r r_{\text {米米 }}$ & $-\cdot / \Gamma \cdot r^{*}$ & $-\cdot /$ FAY & \multirow[t]{2}{*}{$19 / 1 \mathrm{rV}$} & \multirow[t]{2}{*}{$r \cdot / \cdot r$} & \multirow{2}{*}{ اضطراب بدنى اجتماعى } & \multirow[t]{2}{*}{ p } \\
\hline - &.$/ \cdot 1$ & 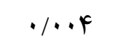 &.$/ \cdots 1$ & & & & \\
\hline
\end{tabular}

$* * \mathrm{p}<\cdot / \cdot 1, * \mathrm{p}<\cdot / \cdot \mathrm{d}$

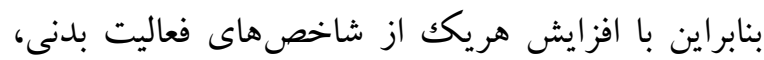
نتايج جدول شماره r حاكى از آن است كه بين اضطراب ميزان اضطراب بدنى اجتماعى كاهش يافته است. با توجه بلدى اجتماعى و شاخصهاى فعاليت بلنى شامل شاخص

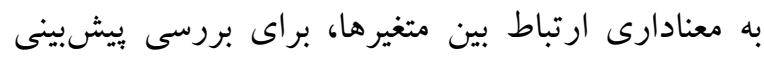
كار، شاخص ورزش و شاخص اوقات فراغت در كل ميزان اضطراب بدنى اجتماعى زنان از روى شاخصهاى

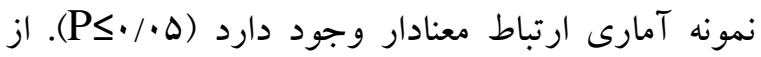

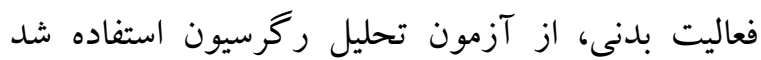
طرفى جهت اين ارتباط منفى به دست آمده است. به

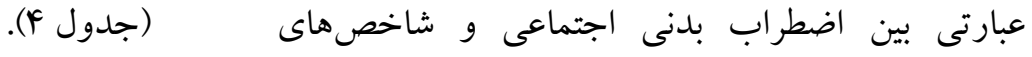
فعاليت بدنى زنان ارتباط منفى معنادار وجود دارد؛

\begin{tabular}{|c|c|c|c|c|c|c|}
\hline سطح معنادارى & تى & ضريب تعيين & معنادارى & مقدار تى & مقدار بتا & متغير \\
\hline \multirow[t]{3}{*}{.$/ \cdot 1$} & $0 / 9.9$ & $\cdot / r r$ & $.1 \cdot 1$ & $-Y / V F \Delta$ & $-\cdot / \pi \mu^{4}$ & شاخص كار \\
\hline & & & $\cdot / \mathrm{V}$ & $-\cdot / 4 \cdot 1$ &.$- / \cdot \Delta r$ & شاخص ورزش \\
\hline & & & $\% r$ & $-1 / N r$ & $-\cdot / r \cdot V$ & شاخص اوقات فراغت \\
\hline
\end{tabular}

شاخص كار مىتواند اضطراب بدنى اجتماعى را بيش بينى نمايد.

بحث يذيرش ظرافت و لطافت زنانه به عنوان يك تفاوت جسمانى نسبت به جنس مرد امرى انكار نشدنى است، اما آنجه مهم است اين است كه بدن و ظاهر زن به نمادى

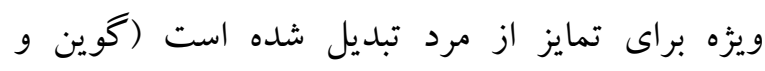

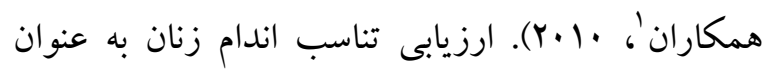
بخش مهمى از مسائل روزمره در جامعه كنونى تلقى مى -
شاخصهاى فعاليت بدنى شامل شاخص كار، شاخص ورزش و شاخص اوقات فراغت وارد معادله رگرسيون

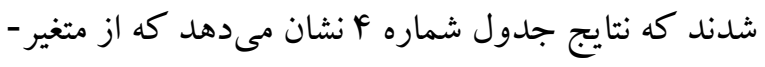
هاى شاخص كار، شاخص ورزش و شاخص اوقات فراغت مىتوانند اضطراب بدنى اجتماعى را در زنان ييشبينى كند. با توجه به معنادارى مقدار F و ضريب تعيين به دست آمده اين متغيرها در مجموع Y Y درصد از واريانس اضطراب بدنى اجتماعى را تبيين مى كنند. همجنين با توجه به معنادارى مقدار t در شاخص كار و ميزان بتاى به دست آمده به مقدار ب م درصد به تنهاى

${ }^{1}$. Gavin et al 
از بيمارىهاى روانى ايجاد جامعه سالم از وظايف نظام آموزشى است. ورزش و فعاليت بدنى برنامهريزىشده، سبب تقويت و بهبود دستگاههاى بدن مانند قلب و تنفس و بهبود آمادگى جسمانى در فرد مىشود، جون جسم و روان انسان مانند يكك جزء واحد عمل مى كنند، لذا مى توان انتظار داشت كه بهبود يكى بر ديخرى اثر مثبت داشته باشد ورزش آثار مفيدى بر روى خلقوخوى افراد

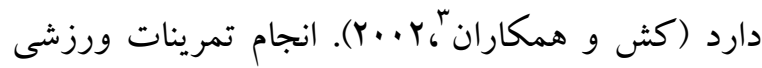
باعث مىشود بدن فشار خون خود را تنظيم كند و سيستمهاى عصبى در مواقع خاصى عكس العمل بهترى

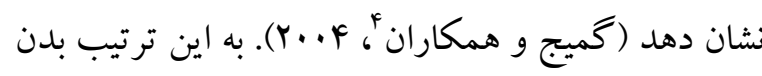
مىتواند كنترل بهترى در شرايط بحرانى و فشارهاى

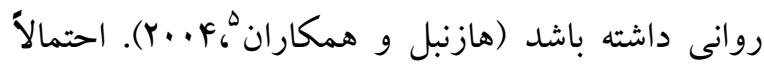
دليل اصلى اثر تمرينات جسمانى، بر شادى و خلق مثبت، آندروفينها هستند كه تأثير اساسى بر اجتماعى بودن و و موفقيتها و كاهش تنش و افسردگى دارند (آل فرمان و

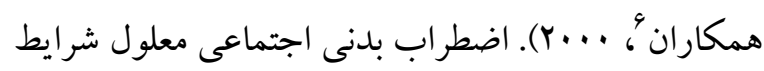
حاكم در محيط زندگى فرد و تعامل اين شرايط با برداشتهاى ذهنى فرد نسبت به بدن خويش است. اين دلايل مىتواند توجيهى براى رابطه معنىدار و ضعيف ميان كمال گرايى و اضطراب بدنى اجتماعى زنان داراى

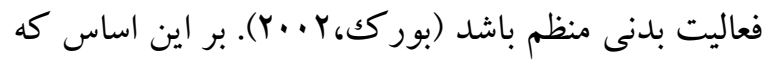

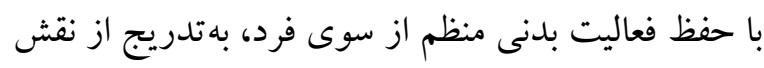

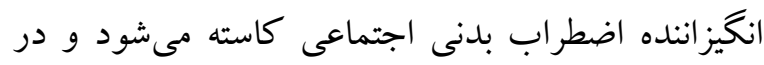
مقابل كمال كرايى و به ويزه خرده مقياس سازماندهى در كنار ديخر عوامل تأثير كذار، همجنان نقش كليدى خود

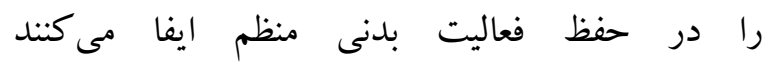

${ }^{3}$.Cash et al

${ }^{4}$. Gammage et al

5 . Hausenblas et al

${ }^{6}$.Alfermann et al
شود، بنابراين تمرين و فعاليتبدنى به عنوان راهى براى تسهيل كاهش وزن و بهبود تركيب بدنى يذيرفته شده

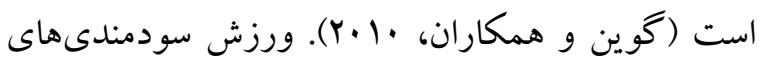
مضاعفى نيز دارد به اين دليل كه به افراد كمكك مى كند احساس بهترى در مورد خود داشته باشند (برى و

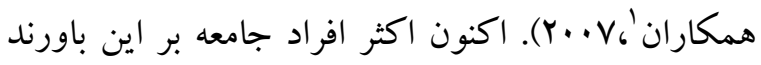
كه مزيت فعاليتهاى بدنى تنها به آثار جسمانى آن

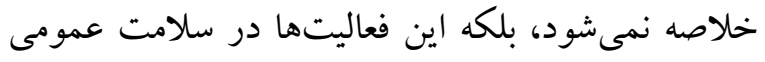
روان افراد به طور كلى و خاص تأثير مى گذارد (برى و

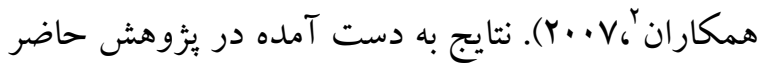
نشان مىدهد كه بين اضطراب بدنى اجتماعى و شاخص هاى فعاليت بدنى شامل شاخص كار، شاخص ورزش و شاخص اوقات فراغت در كل نمونه آمارى ارتباط معنادار وجود دارد. به اين صورت كه با افزايش هريك از شاخصهاى فعاليت بدنى، ميزان اضطراب بدنى اجتماعى كاهش يافته است. هرجه ميزان فعاليت بدنى افراد افزايش يابد بر ميزان سلامت روانى آنان نيز افزوده خواهد شد. افراد با انجام فعاليت بدنى مناسب ضمن بهرهمندى از فوايد جسمى و بهداشتى كاركردهاى روان شناسى و اجتماعى خود را نيز توسعه مىدهند. جمع بندى كلى لى مشخص مى كند كه ميزان سلامت عمومى بيش از نيمى از جامعهى تحت بررسى كمتر از حد متوسط و بيشتر آنها به لحاظ فعاليت جسمانى دجار فقر حر كتى مىشوند هم بستكى خطى و مثبت بين فعاليت بدنى و سلامت وجود دارد كه نشاندهندهى تأثير فعاليت بدنى در بيشخيرى از مشكلات روانى است. از آن جايى كه هدف اصلى سلامت عمومى روان كمكك به همهى افراد و رسيدن به زندكى شادتر و هماهنگ تر شناخت وسيعتر و ييشخيرى

\footnotetext{
1 . Bray et al

${ }^{2}$. Bray et al
} 
نتيجه كيرى

به طور كلى بر بايه يافتهاى تحقيق حاضر جنين استباط مىشود كه يكك رابطه خطى مستقيم بين فعاليت بدنى و رضايت از اندام در زنان ورزشكار وجود دارد. تحقيقات بيشتر در اين زمينه با روشهاى تحقيقاتى ديخرى نياز

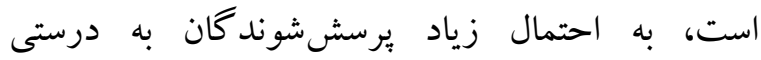

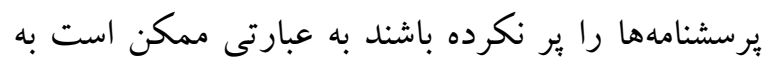
جاى تصوير واقعى از فعاليت بدنى و اضطر اب بدنى سعى در ارائه تصويرى مطلوب از اين فاكتورها نموده باشد. به طور كلى بر بايه يافتهاى حاضر جنين استنباط مىشود

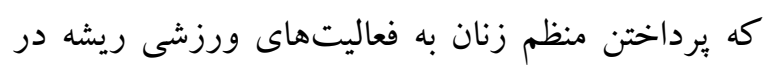
تجربيات كذشته آنها دارد و انتظارات و كيفيت تربيت والدين نقش مؤثرترى در اين راستا دارد. در مطالعه عميدى و همكاران رابطه معنىدارى بين شاخص توده بدنى و نارضايتى از تصوير ذهنى ديده شد. واندرال در ئزوهش خود يِيش بينى كنندهاى معنىدار نارضايتى از تصوير ذهنى بدنى را ترس از ارزيابى منفى و طبقهبندى

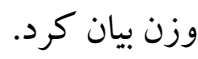

\section{سياسگزارى}

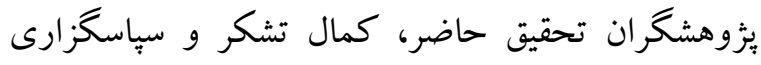
خود را از تمام آزمودنىها كه با دقت تمام يرسشنامهها را مطالعه فرموده و به سؤالات باسخ دادند اعلام مىدارد.

\section{References}

Alfermann D, \& Stoll O. (2003). Effects of physical exercise on self-concept and well-being. International Joumal of Sport and Exercise Psychology. 30, 47-65.

Amidi M, Ghofranipoor F, Hosseini R. (2011). Body image dissatisfaction and body mass index in

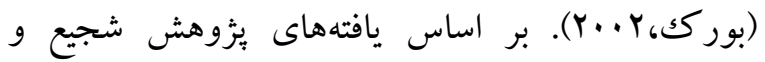

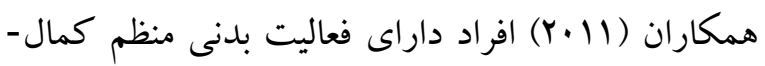
كرا بوده و اضطر اب بدنى كمترى دارند. نتايج نشان داده - كان اند كه شركت در فعاليتهاى ورزشى ابزار مناسبى براى افزايش رفاه ذهنى، عواطف مثبت و رضايت بيشتر از زندگى است. معمولاً تناسباندام در بين زنان در بيشتر جوامع از ارزش بالاترى برخوردار است. هرجه ميزان ارزش و توجه جوامع به تناسب اندام و زيبايى وضعيت بدنى و ظاهر افراد به ويزه در زنان بالاتر مىرود به همان ميزان افرادى كه از معيارهاى تناسب اندام فاصله مى-

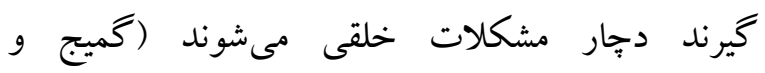

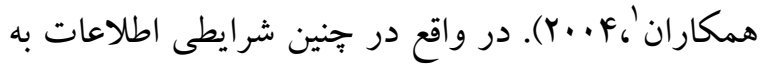
دست آمده و ميزان ارزشمندى تناسب اندام از طريق روابط اجتماعى، رسانهاى گروهى و ديخر مسيرهاى ارتباطى به افراد منتقل مىشود و بدين وسيله راه را بر

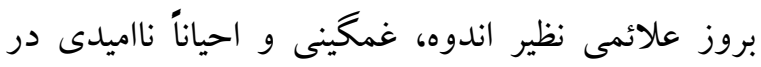

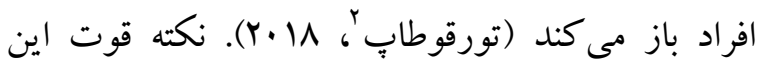
مطالعه جمعيتى بودن آن است، جرا كه نمونه مورد بررسى را مىتوان نماينده مناسبى از جمعيت زنان ورزشكار دانست، همجنين در اين مطالعه به دليل تعداد نمونه به نسبت زياد و كم شدن خطاى اندازه خيرى از طريق به كارگيرى روشهاى استاندارد و انجام آنها توسط يكك نفر، درصد خطاى محاسبه فعاليت بدنى و تناسب اندام بايين آمد. يكى از محدوديتهاى اين مطالعه مقطعى بودن آن است كه نمىتوان به طور مشخص ارتباط علت و معلولى را بين عوامل خطرزاى بروز اضطراب را تحليل نمود.

\footnotetext{
1 . Gammage et al

2. Torgutalp
} 
adolescent girls. Joumal of Research in Behavioral Sciences. 4(1):59-65.

Argayl m. (2001). Translation; bahrami, gohari anaraki, taher neshat doost \& palahang. Publication.university of Esfahan.

Azad Marzabadi E. (2010). Stressor and their relative variables in militants. J Mil Med. 11(4):213-7

Bigdeli I, Karam zadeh S. (2006). The effects of stressors on mental health nurses in Semnan. Semnan Univ Med J. 9(1):8-12.

Bosi MLM, Uchimura KY, Luiz RR. (2009). Eating behavior and body image among psychology students. Jomal Brasileiro de Psiquiatria.58(3):150-5.

Bray SR, Amirthavasar G. (2007). Women exercisers' affective reactions to gender variations in class leaders and co-exercisers. Joumal of Sport \& Exercise Psychology, 30, 146.

Burke SM. (2002). The ideal fitness setting: Does the exercise environment affect social physique anxiety Undergraduate thesis. Hamilton, ON, Canada: McMaster University.

Cash TF, Fleming EC, Alindogan J, Steadman L, Whitehead A. (2004). Beyond contexts: Differences between high and low frequency exercisers. Joumal of Applied Social Psychology, 34, 1638-1651.

Gammage K L, Hall C R, Martin Ginis KA. (2004). Self-presentation in exercise contexts: Differences between high and low frequency exercisers. Joumal of Applied Social Psychology, 34, 1638-1651.

Gavin AR, Simon GE, Ludman EJ. (2010). The association between obesity, depression, and educational attainment in women: the mediating role of body image dissatisfaction. $\mathrm{J}$ Psychosom Res: 69 (6):573-81.

Ghazanfari Z, Niknami S, Ghofranipour F, Hajizadeh E, Montazeri A. (2010). Development and psychometric properties of a belief-based Physical Activity Questionnaire for Diabetic Patients (PAQ-DP). BMC Med Res Methodol: 10(1): 104.

Greenberg AS, Obin MS. (2006). Obesity and the role of adipose tissue in inflammation and metabolism. Am JClin Nutr: 83(2): 461.
Hart E A, Leary MR, Rejeski WJ. (1996). The measurement of social physique anxiety. Joumal of Sport \& Exercise Psychology, 11, 94-104.

Hausenblas HA, Brewer BW, Van Raalte JL. (2004). Self-presentation and exercise. Journal of Applied Sport Psychology, 2004:16,3-18.

Hosseini Esfahani F, Mirmiran P, Djazayeri SA, Mehrabi Y, Azizi F. (2008). Change in food pattems and its relation to alterations in central adiposity in tehranian of district 13 adults. Iran JEndocrinol Metab: 10(4): 299-312.

Karimian R, Rahnama N, Karimi A, Karimian M, Janbozorgi A, Nasirzadeh F. (2013). The effect of physical training on the bumout of nurses in Al-Zahra hospital. J Res Rehabil Sci. 8(5): 870-6.(Persian)

Keyvanara M, Haghighatian M, Kavezadeh A. (2013). Social Factors Influencing Women's Body Image in Isfahan City. Joumal of Applied Sociology. 23(4):53-66.

Mousa TY, Mashal RH, Al-Domi HA, Jibril MA. (2010). Body image dissatisfaction among adolescent schoolgirls in Jordan. Body Image.7(1): 46-50.

Neighbors L, Sobal J, Liff C, amiraian D. (2008). Weighing weight: trends in body weight evaluation among young adults 1990 and 2005. Sex roles.59: 68-80.

Norouzinia R, Aghabarari M, Kohan M, Karimi M. (2013). Health promotion behaviors and its correlation with anxiety and some students' demographic factors of Alborz University of Medical Sciences. J Health Promot Manag. 2(4): 39-49.

Poor sharifi H, Hashemi T, Ahmadi M. (2014). Comparison of social physique anxiety and eating attitudes between obese and normalweight adolescents: the moderating role of sociocultural influence on weight loss and body change. Iranian Joumal of Nutrition Sciences \& Food Technology. 19(2): 49-58. 